\title{
Does Economic Integration Really Improve Trade Competitiveness? The Case of BRICS
}

\section{T.G. Saji}

Department of PG Studies and Research in Commerce \& Management, Sri C Achutha Menon Government College, Thrissur, Kerala, India

Corresponding author: sajthazhungal@gmail.com (ORCID ID: 0000-0003-4763-6164)

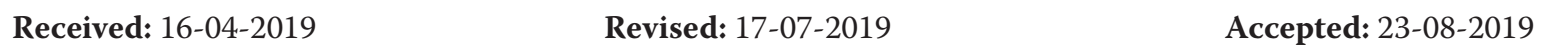

\begin{abstract}
This research assesses the trade competitiveness of BRICS nations during the period 2001-2017. The ultimate aim of the study is to investigate the effects of economic integration in enhancing the trade competitiveness of member countries. Various price and non-price measures that carry information on trade competitiveness are computed and their relative importance is analyzed. The findings of the research demonstrate the asymmetric pattern of trade development in BRICS region even after the formation of group. The benefits under integration are more country specific and in particular, the partnership favors more to the growth of China and India. Surprisingly, the research finds the loosely linked stock markets as and real exchange markets in BRICS that acclaims the lack of consensus among market regulators in their intervention policies.
\end{abstract}

\section{Highlights}

o Divergence exists in BRICS performance

0 Integration benefits skewed in favour of China and India

o Integration affects foreign trade and investments

Keywords: BRICS, Competitiveness, Stock Markets, REER

Integration into the world economy has been proven a powerful means for countries to promote economic growth and development (Ventura, 2005). The ultimate aim of integration by countries is to reduce and remove the barriers to trade thereby ensure the free flow of goods, services and factors of production within the group. There has been increasing number of trade agreements and if they reportedly planned or already under negotiation are concluded, the total number of agreements in force might cross 300 (Nielsen, 2003). The economic reasons for economic integration are simple. Truly integrated economies result in greater world production through the optimum utilization of scarce resources. The countries are able to maximize the production in which they specialized and able to sell surplus in the markets of their trading partners. This will in turn make enhancement in the scale of their trade competitiveness thereby improved earnings. Similarly the higher scale of trade competitiveness attract more amount of capital from overseas market that also can transfer technological, marketing and managerial know how to host economy. Thus, trade competitiveness through growth in export earnings and foreign capital flows stimulate economic growth of the trading partners. In sum, economic theories propose that free trade and investment is a positive sum game in which all the participating economies in the integration stand to gain.

Competitiveness is the extent to which, under liberal market conditions, an economy can produce goods and services that meet the test of global level competition while concurrently enhance 
the real income of its people (OECD, 1992). Competitiveness has close linkage with trade and output growth that expects to bring in improved trade and economic prosperity. The bilateral causality exists between economic growths and exports (Kumar, 2015). Economic integration has been a superior means to improve intraregional trade and exports that emphasizes the competitiveness of national economies (Shams, 2003). The effects of integration can also be visible in the financial market performance of integrating economies (Sum, 2012; Ahmed, 2016). Moreover, the impact of investments on economic growth is not unique (Datta and Lahiri, 2018).

BRICS grouping is one of the most recent economic groupings of nations representing different continents of the world. In terms of size, BRICS is the most substantial economic integration of emerging markets of the world. Economic similarity is a unique feature of BRICS countries. The countries have a large population (almost half of the world population) and vast territories. Moreover, these economies contribute around one-fourth of world GDP. BRICS economies initiated economic reforms almost at similar timelines that have led to higher foreign investments and improved competitiveness. Motivated by their growth potential and regional dominance and seeking leverage to influence global governance system BRICS economies formed their coalition to challenge the supremacy of the developed world (Truman, 2006).

Nine years already elapsed after the formation of the group. Still, literature contradicts with the success of BRICS for its competitiveness. BRICS have widely divergent economies, invest little in each other and have different policy objectives and different forms of government. They are deeply divided on some underlying issues, are rivals rather than allies in the global economy, and have realized very less (Polgreen, 2013). The competitive conditions of BRICS members are quite divergent in terms of many performance dimensions (Pillana 2009). Hence, this study assesses the competitiveness of BRICS integration in terms of both price and nonprice measures during 2001 - 2017. The ultimate aim of this paper is to trace out the integration effects in different performance parameters, including the stocks and currency markets behaviour of the countries in the partnership.

\section{MATERIALS AND METHODS}

\section{Theories and Empirics}

Relative competitiveness has been significant determinant of the gains from trade (Krugman, 1996). Comparative advantage in cost of production explained by the differences in factor endowments contributes to the trade competitiveness (Ohlin, 1933). Competitiveness reflected in the productivity with which nations utilize their human, capital and natural resources determines the economic prosperity (Joshi, 2010). Hence, low labor cost, high productivity of the workforce and proximity to regional markets can determine the trade competitiveness of a nation (Hill and Jain, 2009). The domestic productivity growth and real exchange rate depreciation have a significant positive impact on the international competitiveness of manufacturing industries (Shujaat and Waheed, 2017). However, the importance of factors contributing to country's competitiveness depends on a country's particular stage of development (Porter, 1990). Trade liberalization can cause not only trade expansion but also the increase of foreign direct investment in one country. Trade openness made most countries to adopt radical initiatives to stimulate exports and encourage inward FDIs (Blomstoerm, 1986). Trade agreements should seek to promote consistency between country-level and regional strategies to attain the multifaceted development agenda ahead of trade integration (Santos-Paulino, 2017). Trade integration may produce bad outcomes and there should be domestic policies to make good the possible negative shocks of integration (Gallagher et al. 2005). Industrial competitiveness depends on the smooth functioning of production sector, more specifically for intraregional trade, which is the prime source of vulnerability to possible shocks in member states (Baldwin 2006).

Many empirical studies are also available in determining the effects of integration in different economic settings. Comparing the EU's export performance on the world market with that of its key competitors between 1995 and 2004, Curran and Zignago (2009) show that economic group has performed well, particularly, in the expensive and high tech levels of the market. The new member states constitute the main suppliers of intermediate goods to key EU producers, and thus 
becoming increasingly vital to EU competitiveness. In their study, Bandele and Banga (2017) show the importance of a new preferential trading relationship between CARIFORUM countries and the UK during the post BREXIT arena. Their research views that there is potential to increase exports in the new products and anew trade integration between two economic entities covering both goods and services has potentials to strengthen the trade relations between countries in the alliance. Guan (2004) with his empirical findings on competitiveness of ASEAN integration argues that there are many factors contributing to the fragile competitiveness of member nations and to revive dynamism and competitiveness among them, proper policy realignment and supplementation of the ASEAN process are highly essential. Hill and Menon (2010), in their study on ASEAN integration, observe that there is little chance that ASEAN will emerge into a deep EU-style economic integration behind a common external trade regime due to lack of convergence in domestic policies and higher level of heterogeneity within the region. Adom et al. (2010), using key macroeconomic variables about eight largest African economies during the period 1976 to 2005, investigate the possibility of a full-fledged African Union. Their study find the presence of short term as well as long term macroeconomic interdependence among the countries observed in the research, which is a crucial factor for the success of integration in Africa.

In BRICS context, Pillania (2009) contributes one of the pioneering studies. His research seeks to analyze the competitiveness of emerging markets, particularly Brazil, Russia, India and China (BRIC) countries and finds that India and China are ahead of Russia and Brazil on competitiveness indices, but lag in knowledge indices. De Castro (2012) reviews the progression of trade intensity among BRICs during the period 1995-2009. His assessments are based on the trade intensity index as well as with a closer look at the trade complementary index and RCA. The research reveals Sino-Brazilian and SinoIndian trade as a trade with the highest intensity progression and Russia appears to be the most intensive trade partner for the EU. In a similar type of study, Pingyao and Jing-yun (2012) shows that "BRICS" member countries have dissimilar resource endowment and comparative advantage. However, their economic relationships are not very close and often exists competition within the group. Chen (2012) investigates the linkages between the BRIC economies and the global economy by analyzing their main competitiveness and constraints in the global value chains. His research observes that in the long run BRICS growth might be constrained by technological capabilities; hence they must resort to technological innovation to move up the value chains. De Castro (2012) identifies the main product groups that are involved in BRICS's trade relations, market development and possible trade diversions. The findings reveal that BRICS's exports to markets other than the trade are increasing but consist of less significant product groups. The export intensity review provides proof on BRICS's independent behaviour than the BRICS as a group.

Thanagopal (2013), based on the 16 year (1996 to 2911) highly fragmented sectoral trade, finds the evidence of individual price and non-price competitive effect of BRICS exports towards the major industrialized countries namely EU-14, Japan, United States and Norway. The crux of the finding is that the gain in export market share to BRICS is mostly attributed to better price competition, but not to non-price competition. In another study, Chatterjee et al. (2014) exemplifies the trends in trade and competitiveness among the BRICS members and its special implications for India. Eloquently, the findings portray the complementariness in foreign trade with low levels of competition that can offer prospects for increased intra-BRICS trade and a greater openness in the partnership has the potential to yield gains across the integration. The research of Burange et al. (2013) evaluates the export competitiveness of BRIC for merchandise trade in terms of Revealed Comparative Advantage (RCA) during the period 1997 to 2013. The study finds the absence of convergence in export competitiveness of countries for different commodities. When countries like Brazil, Russia and India enjoy RCA for the natural resource based exports, the BRIC members, excluding China, enjoy export competitiveness for primary goods. Raghuramapatruni (2015) attempts to assess the intensity of trade relations between the BRICS countries with respect to 14 distinct sectors and observe that the BRICS countries are more complimentary rather than competitive to each other. There exists greater potential of multilateral 
trading regime among them, which could hasten the South-South trade. Kurt and Kurt (2015), using panel data and dynamic panel data methods in their study, analyze the short run effects of innovation on labor productivity for BRICS nations. The results of the research confirm the positive relationship between innovation and labor productivity that has been found in many other studies. The findings of the research initiated by Ang (2016) rank the BRICS countries in the order of their competitiveness. The study also differentiates the performance of economies from one another through a meaningful comparison. According to his study, China owns the strongest trade competitiveness in the followed by Russia. Economic growth and fiscal deficit on China is better than the rest of the four countries and the disposable income and per capita in South Africa have the greatest positive affect of foreign trade scale, while the same have no impact to China. China can continue to maintain strong trade competitiveness in the short run, but not necessarily in the long run.

\section{METHODOLOGY}

\section{Data}

The study uses a 17-year annual trade data on five BRICS economies from 2001 to 2017. The total period is logically divided in to two sub periods - Pre integration phase (2001-2010) and post integration phase (20011-2017), for making better understanding on the effects of integration in the trade competitiveness and export performance of BRICS partnership. As it would be almost impossible to incorporate every potential aspect to explain the trade competitiveness, the research limits to specific trade parameters which we identified empirical literature and intuitive trade theory. Accordingly, all the three forms of terms of trade (Gross, Net and Income), Real Effective Exchange Rate (REER), inward Foreign Direct investments (FDIs), Net exports to BRICS and Share in World Exports are used in competitiveness assessment. In addition, five competitiveness indices Relative Export Price Index (REP), Relative Wholesale Price Index (RWPI), Profitability of Exports Index (PEI), Relative Profitability of Exports Index (RPE) and Index of Import Price Competitiveness (IPC) have been compiled to assess the trade competitiveness of member nations in price terms. In addition to this, monthly stock price index data of member countries are used to decide the integration effects in BRICS stock markets. We collect data on input variables from BRICS' Joint Statistical Publications and World Development Indicators database of World Bank. Moreover Bank for International Settlements (BIS) database has been accessed of REER data and OECD database provides the BRICS stock price data.

\section{Compilation of Price Indices}

As we mentioned earlier, the research compiles five indices to measure the competitiveness of BRICS members in price terms. The mode of the compilation of these measures along with the inference to be made on the same is as follows:

REP: The ratio of the unit value index of exports of a country to the weighted average of the unit price of exports of its competitors. REP index below unity indicates higher competitiveness of exports compared to competitors.

RWPI: Country's Wholesale Price Index divided by the weighted average of the indices of its competitor's wholesale prices, which is a useful proxy for domestic costs. A relative WPI below unity shows its competitiveness in the domestic cost of export production.

PEI: The ratio of a country's export unit value to its wholesale price index. Higher export prices relative to wholesale prices makes the producers prefer exports to domestic sale. A PEI of above unity indicates higher profitability.

RPE: The ratio of profitability index of a specific country to weighted profitability index of its competitors. RPE value of more than unity indicates that the export profitability of a specific country is better than its competitor's profitability.

IPC: Country's WPI divided by its unit value index of imports, which, is a measure of the competitiveness of import substitutes for domestic products. An Index of IPC below unity indicates better competitiveness of imports relative to domestic production.

The weight given to each member in BRICS for averaging purposes is calculated based on the following formula:

$$
W_{j}=\sum X_{j} Y_{k} / X_{j} Y_{k}
$$


Where $W_{j}$ is the weight of the $j^{\text {th }}$ country; $X_{j}$ is the export share of a specific country to the world exports; $Y_{j}$ is the export share of a competitor in world exports. The weight given to each competitor reflects the relative importance of that country in a specified country's global markets weighted by the importance of that market to that specified country.

\section{Statistical Tests}

The study does not pursue any rigorous statistical procedure. Simple parametric test analysis provides the needed outputs for the inference. The study uses independent samples t-test to investigate the statistical significance of improvement in trade competitiveness, if any, gained by BRICS partners due to their integration in economic cooperation. Moreover, simple correlation analysis using product moments method traces out the correlation dynamics in BRICS stock and currency markets that spell out the integrative, indirectly independent, structure of BRICS financial markets as the outcome of the economic partnership.

Eq. 1 gives the mathematical expression of $t$ statistic is:

$$
t_{12}=\frac{\bar{x}_{1}-\bar{x}_{2}}{S E}
$$

SE is the standard error with equation (2)

$$
Y_{t}=\frac{\bar{x}_{1}-\bar{x}_{2}}{S E}
$$

The product-moment method of correlation of Karl Pearson (1948) is given in equation (3)

$$
r_{x y}=\frac{\Sigma\left(x_{i}-\bar{x}_{i}\right)\left(y_{j}-\bar{y}_{j}\right)}{\sqrt{\left(x_{i}-\bar{x}_{i}\right)^{2}} \sqrt{\left(y_{j}-\bar{y}_{j}\right)^{2}}}
$$

The $t$ statistic testing the significance of the correlation coefficient is given by equation (4)

$$
t_{r x y}=\frac{r \sqrt{n-2}}{\sqrt{(1-r)^{2}}}
$$

Where $x_{1}$ and $x_{2}$ are respectively, the specific trade parameters in pre-integration and post-integration. The variables in ' $x_{i}^{\prime}$ and ' $y_{i}^{\prime}$ are specific parameters of ' $i^{\text {th' }}$ and ' $j$ th' country, respectively. ' $n_{1}$ ' and ' $n_{2}$ ' are the respective number of observations made.

\section{RESULTS AND DISCUSSION}

\section{Terms of Trade}

Terms of trade' is the prime determinant of the gains from trade to economies. We could observe much divergence in gains from trade to BRICS nations. In gross terms, the gains from global trade are quite promising to Russia and South Africa. These two economies are endowed with abundant but valuable natural resources hence need a lesser amount of imports to balance their trade. With a vast landmass and extensive natural resources, enable Russia to enjoy absolute cost advantage, particularly in oil and natural gas exports. The country gains from trade during the years of surging oil prices because of which it can make more significant export earnings with fewer exports in quantities. South Africa is rich in mineral resources including chromium, platinum, manganese and iron ores that constitute about 50 per cent of the economy's total exports. The higher level of diversification allows South Africa to gain more through better export prices. Another important observation to be made here is that the improvement in gross terms of trade has gone hand in hand with considerable variability in terms of trade.

The positions of China and India are fairly distinct from the rest of the group, not only in their trade concentrations but also in their import needs (Table 1). While China is industrially competitive with a solid manufacturing base, India has more service orientations in her trade portfolios. The demand for the raw natural mineral resources including oil by the emerging economic powers from Asia, China and India, have translated into higher imports, but only at the cost of a larger amount of exports causing lower their terms of trade. However, the larger degree of export diversification in Asian economies resulted in lower terms of trade variability. Brazil, which was least in position gained significant enhancement the figure of their terms of trade. It is quite curious to note that the BRICS integration enabled its trading partners, except China to make better their positions at a significant rate. The demand for Chinese exports has increased terrifically, particularly after the global recession, which might be the possible reasons for the larger sacrifice of exports for meeting the import requirements in China. 
Table 1: Effects of BRICS Integration in Terms of Trade of Member Nations

\begin{tabular}{ccccc}
\hline Terms of Trade & Country & Pre integration & Post integration & $\mathbf{t}$ statistic \\
\hline \multirow{4}{*}{ Gross } & Brazil & 0.76 & 1.12 & ${ }^{*} 5.633[0.000]$ \\
& Russia & 1.79 & 2.59 & ${ }^{*} 2.887[0.013]$ \\
& India & 1.02 & 1.18 & ${ }^{*} 3.268[0.006]$ \\
& China & 0.87 & 0.79 & ${ }^{* *}-2.132[0.053]$ \\
& South Africa & 1.36 & 1.60 & ${ }^{*} 2.186[0.048]$ \\
\hline \multirow{4}{*}{ Net } & Brazil & $1.37 .232[0.007]$ \\
& Russia & 0.75 & 1.09 & $*-2.426[0.031]$ \\
& India & 0.89 & 0.69 & $-1.745[0.105]$ \\
& China & 1.05 & 0.80 & $0.236[0.817]$ \\
& South Africa & 0.86 & 1.06 & $0.254[0.803]$ \\
\hline \multirow{4}{*}{ Income } & Brazil & 222.32 & 0.87 & $-0.395[0.699]$ \\
& Russia & 104.40 & 212.54 & $* 1.778[0.091]$ \\
& India & 163.33 & 314.64 & $* 7.903[0.000]$ \\
& China & 304.94 & 653.00 & $* 4.711[0.000]$ \\
& South Africa & 92.88 & 116.11 & $* 4.607[0.000]$ \\
\hline
\end{tabular}

Notes: Figures in parenthesis indicate p-value

*significant at 1 per cent level; ${ }^{* *}$ significant at 5 per cent level; ${ }^{* * *}$ significant at 10 per cent level

Export and import price indices are useful tools in international economics (Gaulier, Martin, Mejean and Zignao 2008). Only two economies in the group, Brazil and China are making gains from global trade in net terms. The average export prices of these two economies are higher than average prices at which they make their imports. The rest of the group has to pay larger import prices than their export prices. The comparative advantage of these economies in the production of specific products, for example, China in electronic products and Brazil in oil and natural gas, enjoy a lower cost of production and command better prices in markets. However, after integration, we can see significant contractions in term of trade to Brazil, despite its value greater than unity. In the case of the remaining three members, Russia, India and South Africa, the gains from trade do not exist nor do their partnerships in the integration produce any impact in this regard. Russia proved to be the least beneficiary in net terms of trade.

The Income Terms of Trade reflects the gains from trade in a single measure reflecting both volume and price performance of the trade. According to Income terms, China, followed by India, are the economies who received more considerable gains from trade, particularly after integration. Nevertheless, China's gains from trade are more than double that of India, and this relationship persisted in both periods. Among the remaining member countries, Brazil out beats Russia and South Africa in producing gains from trade with the global economy. The benefits to Russia and South Africa from their global trade were almost at the same rate. A close observation reveals that the BRICS integration has produced positive effects in (income) terms of trade to all partners except Brazil. On consolidating our observations, unarguably, we can say that China and India are the biggest beneficiaries of BRICS integration.

\section{Price Competitiveness}

REP is most significant in assessing the performance of economies with more export orientations in their trade portfolios. In terms of REP, the export performance of China and Russia are far ahead of other member nations and Brazil is found to be the least competitive in the group (Table 2). Brazilian manufacturers are losing markets to Chinese competitors in a range of products (Murphy et al. 2007; Jenkins, 2010), and this could be reasons for the lower competitiveness of Brazil. However, the REP of China has been consecutively increasing, and the trend may pose some problems in its export end. There was a constant increase in South Africa's REP that reached above unity. 
Nevertheless, it is worth to note that after its joining in the grouping, the REP measure of South Africa has straightly declined which, impels the betterment in competitiveness and increased economic benefits for its entry into the group. As far as India is considered, the country's trade Competitiveness defined by REP was less than unity indicating the higher competitiveness before the integration, and some increases are occurred to reach unity after integration. Based on this pattern in REP, the formation of the BRICS group is much skewed in enhancing trade competitiveness and generating benefits in economic terms to member nations.

Relative Wholesale Price Index is a useful proxy for domestic costs of the BRICS group. China is the only country whose RWPI fell below unity after the formation of BRICS. It shows the competitiveness of China in the domestic cost of export production.
The trend in the remaining members is quite the opposite. Their RWPI are constantly increasing, which later took it to the above unity after the formation of the economic group. From this, it is truly logical to infer that the economic integration of BRICS countries become critical for China to become more competitive in terms of its cost of production of goods exported. Cheap labour, undervalued currency and subsidies define the economics of lower Chinese prices (Navarro 2006). Manufacturer sector in China is nearly five times more productive than in India (Dhawan et al. 2012). This observation is not much surprising since the dragon, under the terms of integration, the country that focuses intensively more on batch production gets more marketing opportunities to dump their surplus production that enable it to make full use of its economic capacity leading to mass production and lower cost per unit.

Table 2: Effects of Integration in BRICS Competitiveness

\begin{tabular}{|c|c|c|c|c|}
\hline Indicators & Country & Pre integration & Post integration & t statistic \\
\hline \multirow{5}{*}{ REP } & Brazil & 1.16 & 0.89 & $* 3.621[0.003]$ \\
\hline & Russia & 1.19 & 0.92 & ${ }^{*} 4.194[0.001]$ \\
\hline & India & 0.87 & 1.01 & *-4.548 [0.005] \\
\hline & China & 0.85 & 1.12 & *-3.411 [0.005] \\
\hline & South Africa & 1.16 & 0.82 & *3.067 [0.009] \\
\hline \multirow{5}{*}{ RWPI } & Brazil & 0.91 & 1.12 & *-3.549 [0.004] \\
\hline & Russia & 0.76 & 1.19 & ${ }^{*}-4.885[0.000]$ \\
\hline & India & 0.93 & 1.12 & *-5.278 [0.000] \\
\hline & China & 1.29 & 0.85 & $* 4.525[0.001]$ \\
\hline & South Africa & 0.92 & 1.10 & *-4.218 [0.001] \\
\hline \multirow{5}{*}{ PEI } & Brazil & 0.75 & 0.96 & $* * 2.339[0.036]$ \\
\hline & Russia & 0.89 & 0.96 & $0.591[0.564]$ \\
\hline & India & 0.60 & 1.08 & *4.698 [0.000] \\
\hline & China & 0.56 & 1.30 & *5.854 [0.000] \\
\hline & South Africa & 0.74 & 0.89 & $* * * 1.854[0.087]$ \\
\hline \multirow{5}{*}{ RPE } & Brazil & 1.25 & 0.80 & *-3.486 [0.006] \\
\hline & Russia & 1.60 & 0.80 & ${ }^{*}-4.819[0.000]$ \\
\hline & India & 0.89 & 0.90 & $0.129[0.899]$ \\
\hline & China & 0.68 & 1.37 & ${ }^{*} 4.093[0.001]$ \\
\hline & South Africa & 1.21 & 0.75 & ${ }^{*}-4.000[0.002]$ \\
\hline \multirow{5}{*}{ IPC } & Brazil & 1.70 & 1.04 & *3.085 [0.009] \\
\hline & Russia & 1.31 & 1.12 & $0.963[0.353]$ \\
\hline & India & 2.31 & 0.95 & ${ }^{*} 2.637[0.021]$ \\
\hline & China & 2.27 & 0.81 & $* * 3.034[0.012]$ \\
\hline & South Africa & 1.32 & 1.07 & $1.238[0.238]$ \\
\hline
\end{tabular}

Notes: Figures in parenthesis indicate p-value

*significant at 1 per cent level ** significant at 5 per cent level ** significant at 10 per cent level 
The trade performance of BRICS economies is quite dissimilar in price terms of PEI and RPE. China remains more competitive and outperforms its partners in the group. Both price indices of China, RPE and PEI have almost doubled during the period. Lower manufacturing costs and growing market share has made the Chinese exports more lucrative in the integration. Russia and India come into sight as the next best two in competitiveness in the group. The exports profitability of India has significantly improved despite there has not been any change in this regard relative to the other competitors from the group. The uniqueness of India from other emerging economies is its service-led growth and the recovery of the world economy from the recession has brought in significant improvement in the profits from service exports. Russia, which was well performer before integration, met contractions in export earnings leading to declined profits. The rest of the group, Brazil and South Africa are far behind their peers in terms of all price measures. A steep decline in the index of RPE is observed, while considerable improvement in export profitability is noticed. The convergence in competitiveness in PEI terms and divergence in RPE terms reveals that the integration benefits all the BRICS partners, but the effects of the partnership are not even among the group. In terms of these two measures, also, China and India outpaced others by the integration.

The BRICS partnership enhances the competitiveness of member nations in their import trade. Before the integration, none of the members was found competitive as their IPC were above unity. However, import competitiveness of all the countries has significantly improved, which is evident from the index of their import competitiveness. More deep analysis again support our previous claim that China and India are the two-member nations who have most benefited by the agreement. The Chinese and India competitiveness in transacting their import trade consolidated well after the formation of the BRICS group and the numeric value measuring their competitiveness reached the favourable position of below unity during post integrative phase.

\section{External Sector Performance}

The external sector performance of BRICS partners is not even in both periods of analysis. The REER of members, except South Africa and India depreciated much. Ruble and Brazilian Real sustained sharp reductions in value, while the mean difference in real effective exchange values of Indian rupee is found marginal. The plunging real exchange currency values of Russia and Brazil are quite worrying when we look at this fall in the light of the inelastic demand structure of their exports consisting of oil and natural resources. However, devaluation of the Chinese currency against the currency values of its trading partners need not be seriously looked into as its central bank, for the country's interest, keeps the Yuan artificially low to make its growing export industry more competitive against rivals. Real exchange values of South African Rand have come out with odd behaviour against others.

The BRICS countries have been the leading recipients of overseas capital for the last many years. Multinational Corporate have been taking their operations to BRICS nations to take advantage of its low labour and natural resources costs and huge domestic market demand from the mass population. Like in other parameters, China is continued to be unbeaten in winning investor confidence. Brazil and Russian Federation liberalized their economies with the least restrictions and received more amount of FDI. The capital flows to Brazil are relatively large and significant in the integration. Although the share of world FDI to South Africa is lowest in the group, the country can attract foreign capital almost at a constant rate. Indeed, India's share in total BRICs FDI is relatively low, yet powered by the service sector boom the 'tiger' can make remarkable growth in receipt of capital. However, the absorptive capacities of the host economies in terms of their supportive activities need to be scrutinized while assessing the FDI effects in BRICS in the economy.

China and Brazil are export economies with positive trade balances, while the remaining partners have negative balances in their trade accounts. China is far ahead of other partners in making revenues from global trade. While the Chinese export earnings almost doubled after integration, the Brazilian exports significantly declined, which reinstate our earlier claim that Brazilian manufacturers are losing their markets to low-cost Chinese exporters. Import competitiveness of India and Russia revealed earlier has widened the negative balances in their current 
Table 3: Effects of BRICS Integration in External Sector Performance

\begin{tabular}{|c|c|c|c|c|}
\hline Indicators & Country & Pre integration & Post integration & $\mathrm{t}$ statistic \\
\hline \multirow{5}{*}{ REER } & Brazil & 70.08 & 91.9 & *3.193 [0.007] \\
\hline & Russia & 91.32 & 112.48 & ${ }^{*} 4.802$ [0.000] \\
\hline & India & 93.29 & 95.34 & $1.020[0.326]$ \\
\hline & China & 80.48 & 98.20 & $* * 2.708[0.018]$ \\
\hline & South Africa & 88.39 & 87.46 & $-0.166[0.870]$ \\
\hline \multirow[t]{5}{*}{ Inward FDI } & Brazil & 255.26 & 861.65 & *8.624 [0.000] \\
\hline & Russia & 277.77 & 411.57 & $* * 2.043[0.046]$ \\
\hline & India & 167.73 & 324.38 & $* *-2.353[0.035]$ \\
\hline & China & 1014.64 & 2610.84 & *7.729 [0.000] \\
\hline & South Africa & 46.08 & 46.67 & $-0.035[0.973]$ \\
\hline \multirow[t]{5}{*}{ Net Exports } & Brazil & 53.52 & 32.76 & 1.576 [0.139] \\
\hline & Russia & -85.00 & -204.23 & *3.663 [0.003] \\
\hline & India & -52.09 & -168.36 & *4.074 [0.001][ \\
\hline & China & 22.17 & 44.69 & *3.724 [0.000] \\
\hline & South Africa & -36.18 & -49.14 & ${ }^{* * *}-1.762[0.091]$ \\
\hline \multirow[t]{5}{*}{ Export share } & Brazil & 1.10 & 1.28 & $* 3.501[0.004]$ \\
\hline & Russia & 2.21 & 2.63 & $* * * 2.011[0.065]$ \\
\hline & India & 0.97 & 1.65 & *7.088 [0.000] \\
\hline & China & 7.23 & 11.63 & *5.006 [0.000] \\
\hline & South Africa & 0.43 & 0.50 & ${ }^{* *} 2.280[0.040]$ \\
\hline
\end{tabular}

Notes: Figures in parenthesis indicate p-value

*significant at 1 per cent level; **significant at 5 per cent level; ***significant at 10 per cent level.

accounts through enhanced imports trade. The entire BRICS bloc can widen their market share, where China is again overriding with more than ten per cent in world exports. The export share of China is more than five times that of Russia, the next best performer in the group. Brazil was in the third position, is overtaken by India with almost doubling its market share. However, still, the share of India in world exports market is less than 2 per cent. The presence of South Africa in global trade is weak with a very meagre market share.

\section{Correlations among BRICS Financial Markets}

The research compares the financial markets performance in BRICS during pre and postintegration. We observed two segments of the financial markets, stock markets and (real) foreign exchange markets, of the BRICS nations. The ultimate aim of this analysis is to investigate how the integration would have been affected the investment potentials in the markets we selected.

Correlation results in Table 4 reveal the existence of stronger co-variation among BRICS stock markets before the formation of the integration. It is very curious to note that the stock price movement in each country has embraced close relation with price changes in other markets.

Table 4: Correlation among BRICS Stock Markets

\begin{tabular}{ccc}
\hline & Pre integration & $\begin{array}{c}\text { Post } \\
\text { integration }\end{array}$ \\
\hline Brazil \& Russia & ${ }^{*} 0.901[0.000]$ & $0.416[0.177]$ \\
Brazil \& India & ${ }^{*} 0.994[0.000]$ & $0.053[0.455]$ \\
Brazil \& China & ${ }^{*} 0.755[0.006]$ & $0.002[0.498]$ \\
Brazil \& South Africa & ${ }^{*} 0.976[0.000]$ & $-0.166[0.361]$ \\
Russia \& India & ${ }^{*} 0.938[0.000]$ & ${ }^{* *} 0.753[0.025]$ \\
Russia \& China & ${ }^{*} 0.744[0.007]$ & ${ }^{* *} 0.730[0.031]$ \\
Russia \& South Africa & ${ }^{*} 0.956[0.000]$ & $* * 0.609[0.073]$ \\
India \& China & ${ }^{*} 0.767[0.005]$ & ${ }^{* *} 0.720[0.034]$ \\
India \& South Africa & ${ }^{*} 0.988[0.000]$ & ${ }^{*} 0.959[0.000]$ \\
China \& South Africa & ${ }^{*} 0.803[0.003]$ & $* * 0.595[0.079]$ \\
\hline
\end{tabular}

Notes: Figures in parenthesis indicate p-value

*significant at 1 per cent level; ** significant at 5 per cent level; ***significant at 10 per cent level. 
However, on observing the values of the correlation coefficients, it is quite clear that the integration of Chinese markets with other markets was relatively at a lower degree, which seems to be the results of the exceptional performance of the 'Dragon' relative to its peers in the group. An almost perfect linear relationship exists among India, Brazil and South Africa, which implies that arbitrage opportunities to portfolio investors were almost absent. Surprisingly after the integration of the economies, the degree of the interrelationship among markets are straightly diminished. The Brazilian market has behaved much indifferently towards the performance of the remaining markets. The co-movement in Indian and South African stock prices are almost perfect, while Chinese markets hold relatively high positive correlation with markets other than the Brazilian market. The co-variation between stock prices in India and Russia are also found relatively high and positive. Positive, but imperfect pattern of the relationship held by the stock markets (except Brazil) in the economic bloc radically impede the global investors in reaping the benefits through portfolio diversification over BRICS markets.

The price movements in foreign exchange markets of BRICS were relatively independent before they are joining in the group (Table 5).

Table 5: Correlation among BRICS Foreign Exchange Markets

\begin{tabular}{ccc}
\hline & Pre integration & Post integration \\
\hline Brazil \& Russia & $0.280[0.232]$ & ${ }^{*}-0.968[0.001]$ \\
Brazil \& India & $0.420[0.130]$ & $0.262[0.308]$ \\
Brazil \& China & ${ }^{*} 0.964[0.000]$ & ${ }^{* *} 0.804[0.027]$ \\
Brazil \& South Africa & $0.052[0.447]$ & ${ }^{*} 0.885[0.012]$ \\
Russia \& India & $-0.297[0.291]$ & $-0.364[0.239]$ \\
Russia \& China & $0.095[0.404]$ & $* *-0.747[0.044]$ \\
Russia \& South Africa & ${ }^{*}-0.766[0.008]$ & $* *-0.953[0.002]$ \\
India \& China & $0.442[0.117]$ & $-0.327[0.264]$ \\
India \& South Africa & $0.237[0.269]$ & $0.566[0.121]$ \\
China \& South Africa & $0.156[0.344]$ & $0.580[0.114]$ \\
\hline
\end{tabular}

Notes: Figures in parenthesis indicate p-value

*significant at 1 per cent level; ** significant at 5 per cent level; ***significant at 10 per cent level

Our correlation analysis finds a significant correlation in the real exchange rates of only two economies, Brazil and China; both are export-driven economies. The forex markets of the rest in the group are either uncorrelated or loosely correlated. However, the analysis could observe a relatively more significant negative correlation between Russia and South Africa, and there seems to be nothing worth to infer from such a relationship.

However, analysis of co-variation among BRICS exchange rates during the post-integration period observed incremental relationship among markets. A more substantial positive and significant correlation is revealed among three exchange rate markets, Brazil, China and South Africa. It is interesting to note that the responses of Russian ruble are highly adverse to the currency movements in the rest of the group. The plummeting ruble prices are alarming to Russian business as they need more amount of dollars and Euros to service their overseas debts. The rupee responses to Brazilian real are positive and to Chinese Yuan are negative, but are insignificant in both cases. Even though increased convergence in exchange rates are visible in BRICS markets after integration, the observed facts do not offer sufficient freedom for us to infer that the central banks in member nations are yielding to harmonize their policies in monetary and market intervention matters.

\section{CONCLUSION}

This research assesses the competitiveness of BRICS cooperation in terms of select price and nonprice measures. The study found more amount of divergence than convergence in the performance of the BRICS partnership. The Chinese economy out beats all other partners in the group in almost all dimensions of competitiveness. The exports of China are found much profitable, and the country enjoys a stronger degree of competency at its imports end. The formation of integration is more benefitted to 'Dragon', and the same is visible in its expanded export trade, spanning export share and mounting inward FDIs. The Indian economy has also been gained by the partnership in terms of increased FDI inflows, stretched export share, improved export profitability, and reduced imports cost. The benefits of integration to other members are found only partial and mainly reflected in their exports and FDI receipts. In a nutshell, the synergetic impact of economic integration on BRICS members' competitiveness has been reflected at three levels; profitable exports cost-efficient imports 
and consolidated capital base.

The correlation results show that the degree of stock market integration, which, was very strong before the formation of the partnership, now loosely, linked even after seven years of BRICS cooperation. However, the imperfect positive correlation, existed at a relatively larger rate, among the partners' stock markets reduce the scope for global investors to diversify their investment risks through deploying funds in BRICS markets. The research could not find complete consensus among the central banks of BRICS partners in designing their market intervention policies. In most cases, the co-movement in real exchange rates of the member countries are either indifferent or insignificant. Thus, BRICS partnership needs more convergences in their policy framework to form a currency union like Eurozone that challenges the hegemony of G7 developed nations in international polity and economy.

The findings and implications of this research are limited to the select aspects of the competitiveness of the BRICS group. Many other parameters like inflation, interest rate, human capital, technology development and many other parameters that embed into the performance of the economies need to be assessed for making a more meaningful conclusion about the success of BRICS partnership. The study covers only a short period annual data from 2001 to 2017, which is only available at present, and its analytic design did not include any rigorous econometric framework. Hence, we should wait for a longer period and administer more sophisticated panel regression framework to enhance further the validity and significance of this kind of research.

\section{REFERENCES}

Adom, A.D., Sharma, S.C. and Morshed, A.K.M. 2010. Economic integration in Africa', Quart. Rev. Econ. Finance, 50(3): 245-253.

Ahmed, A. 2016. Integration of financial markets, financial development and growth: Is Africa different? J. Int. Financ. Mark. Inst. Money, 42(c): 43-59.

Baldwin, R.E. 2006. Multilateralising regionalism: Spaghetti bowls as building blocs on the path to global free trade. World Economy, 29: 1451-18.

Bandele, O. and Banga, R. 2017. Brexit: challenges and opportunities for Jamaica and other CARIFORUM countries. Trade Competitiveness Briefing Paper 2017/03, Commonwealth Secretariat, London.
Blomstoerm, M. 1986. Foreign investment and productive efficiency. The case of Mexico. J. Ind. Econ., 15: 97-110.

Burange, L.G., Ranadive, R.R. and Karnik, N.N. 2013. Trade openness and economic growth nexus: a case study of BRICS', Working Paper No. 1, ISF Institute of Research and Education (IIRE). Available at http://iire. in/WorkingPapers/IIRE-WP-\%2013-11-2014 Trade\%20 Openness\%20and\%20Economic\%20Growth\%20Nexus. pdf

Chen, L. 2012. The BRICS in the global value chains: an empirical note. Cuadernos de Economía, 31(57): 221-239.

Chatterjee, B., Jena, P.C. and Singh, S. 2014. Intra BRICS trade and its implications for India. Discussion paper, CUTS International. Available at www.cuts-citee.org/pdf/IntraBRICS_Trade_and_its_Implications_for_India.pdf

Curran, L. and Zignago, S. 2009. Evolution of EU and its member states. Competitiveness in International Trade, CEPII Working Paper 2009-11. Available at SSRN: https:// ssrn.com/abstract $=1532718$ or http://dx.doi.org/10.2139/ ssrn.1532718

De Castro, T. 2012. Trade cooperation indicators: development of BRIC bilateral trade flows. International Review of Business Research Papers, 8(1): 211 -223.

Dhawan, R., Swaroop, G. and Zainulbhai, A. 2012. Fulfilling the promise of India's manufacturing sector', McKinsey. Available at https://www.mckinsey.com/businessfunctions/operations/our-insights/fulfilling-the-promiseof-indias-manufacturing-sector

Gallagher, P., Low, P. and Stoler, A. 2005. Managing the Challenges of WTO Participation: 45 Case Studies, Cambridge, Cambridge University Press.

Gaulier, G., Martin, J., Mejean, I. and Zignago, S. 2008. International trade price indices, CEPII Working Paper 2008-10.

Guan, B.T.C. 2004. ASEAN's regional integration challenge: the ASEAN process. The Copenhagen Journal of Asian Studies, 20(2): 70-94 .

Hill, C.W.L. and Jain, A.K. 2009. International Business. New Delhi: Tata McGraw-Hill Education.

Hill, H. and Menon, J. 2010. ASEAN Economic Integration: Features, Fulfillments, Failures and the Future. $A D B$ Working Paper Series on Regional Economic Integration No.69. Available at https://www.adb.org/sites/default/files/ publication/28551/wp69-hill-menon-asean-economicintegration.pdf

Jenkins, R. 2010. China's global expansion and Latin America. J. Lat. Am. Stud., 42(4): 809-937.

Joshi, R.M. 2010. International Business. New Delhi: Oxford University Press.

Krugman, P. 1996. Making sense of the competitiveness debate', Oxf. Rev. Econ. Policy, 12(3): 17-25.

Kurt, S. and Kurt, U. 2015. 'Innovation and labour productivity in BRICS Countries: Panel causality and co-integration. Procedia - Social and Behavioral Sciences, 195: 1295-1302. 
Murphy, H.C. Swann, and Drajem, M. 2007. Economic outlook: competition from China squeezes developing countries. International Herald Tribune, 2.

Navarro, P. 2006. The economics of the China price. Chin. Pers., 68: 13-27.

Ohlin, B. 1933. Interregional and International Trade. Cambridge: Harvard University Press.

Pillania, R.K. 2009. Competitiveness and emerging markets. Bus. Strat. Ser., 10(2): 90-95.

Pingyao, L. and Jingyun, W. 2012. Opportunities and challenges faced by the cooperation of BRICS. Statistical Research, 29(2): 21-27.

Polgreen, L. 2013. Group of emerging nations plans to form development bank. The New York Times. Available at https://www.nytimes.com/2013/03/27/world/africa/bricsto-form-development-bank.html

Porter, M. 1990. The competitive advantage of nations. New York: The Free Press.

Raghuramapatruni, R. 2015. Revealed comparative advantage and competitiveness: a study on BRICS. Arab J. Bus. Manage Rev., 5(5): 1-7.

Santos-Paulino, A.U. 2017. The Asian economic integration cooperation agreement: lessons for economic and social development UNCTAD Research Paper No. 3. Available at https://unctad.org/en/PublicationsLibrary/ser-rp2017d3_en.pdf
Shams, R. 2003. Regional integration in developing countries: some lessons based on case studies. HWWA Discussion Paper 251, Hamburg Institute of International Economics, Available at https://ageconsearch.umn.edu/ bitstream/26272/1/dp030251

Shujaat, A. and Waheed, A. 2017. Trade competitiveness of Pakistan: evidence from the revealed comparative advantage approach. Competitiveness Review, 27(5): 462475 .

Sum, K. 2012. The integration of the financial markets and growth evidence from a global cross-country analysis. Bank $i$ Kredyt., 43(3): 47-70.

Thanagopal, T. 2013. Analyzing BRIC competitiveness in the EU-14, Japan, US and Norway. Duncker and Humblot, 61(3): 229-260

Truman, E.M. 2006. Implications of structural changes in the global economy for its management. World Economic Forum. Available at https://piie.com/publications/papers/ truman0306.pdf

Nielsen, C.P. 2003. Regional and preferential trade agreements: a literature review and identification of future steps. FOI Rapport, No. 155, University of Copenhagen. Available at https://curis.ku.dk/ws/files/127718299/FOI_Rapport_155. pdf

Ventura, J. 2005. A global view of economic growth, in Aghion, P. and S.N. Durlauf (eds.), Handbook of Economic Growth, North Holland, Elsevier Academic Press 1B: 1419-1497. 